\title{
The Morphology of Riccia Frostii, Aust.
}

\author{
BY \\ CAROLINE A. BLACK. \\ With Plates XXXVII and XXXVIII.
}

\section{General Characters.}

$\mathrm{T}$ $\mathrm{HE}$ summer and autumn of 1908 were characterized by an exceedingly long drought in Bloomington, Indiana. During the autumn, as the water in the reservoir which supplied the town gradually diminished, the basin of the reservoir was covered with patches of Riccia Frostii, Aust. ${ }^{1}$ The ground in its moist condition, roughened by cracks as a crust gradually formed, provided an ideal habitat for the Liverwort, as evidenced by its luxuriant growth. Tracks made by workmen, horses, \&c., furnished further protection and conservation of water, and on the border of these the plants were also numerous. The Liverwort was found in patches several metres square, or in solitary rosettes, and in colour appeared dull green to reddish. The following years, I909-IO and I9IO-II, although dry, never exhausted the water in the reservoir. Comparatively little Riccia was found, and this only on the banks of the reservoir. Riccia Frostii was described as a new species by C. F. Austin (2) in I 875. Underwood (42) includes Riccia Frostii in his Hepaticae, and describes it fully.

Riccia Frostii, Aust., when grown uncrowded develops a thallus, in form a typical rosette, varying in diameter from 5 to $12 \mathrm{~mm}$, attached to the ground by simple rhizoids. Young plants are irregularly and more deeply lobed than older, fully developed ones. This is well shown in Pl. XXXVII, Figs. I-5, which are photographs of plants, enlarged four times. The central portion sometimes decays as the plant grows, and results in unsymmetrical rosettes. There is present a dichotomous branching which gives rise to a circular plant, with a number of growing points situated in depressions at the edge of the rosette (Figs. I and 2). As a whole the thallus is compact (Figs. I and 2). When the plants are found growing under crowded conditions, the typical rosette form is lost in the overlapping of the different plants, which pile up and grow irregularly as they encroach upon each other. The

1 Acknowledgement is due to Mr. Marshall A. Howe, who kindly determined the species as Riccia Frostii, Aust.

[Annals of Botany, Vol. XXVII. No. CVII. July, 1913.] 
surface of the thallus is characterized by minute depressions or pits corresponding to the air-spaces beneath. Underwood describes the thallus of Riccia Frostii as probably dioecious. It was found to be strictly dioecious. It begins to fruit when very young, and a succession of sexual organs is maintained as the thallus develops. Plants only 3 or $4 \mathrm{~mm}$. in diameter were found with mature sporophytes. The globular sporophytes were seen readily with the naked eye, the older ones appearing black.

The abundance of material found in all stages of development, together with the interest in recent years in various phases of the life-history of different Liverworts, suggested the desirability of making a study of this plant. Material was fixed in chromacetic acid, and in the chrom-osmicacetic acid mixture prepared according to the formula of Mottier (36), washed, dehydrated, and embedded in paraffin. Sections were cut from 2 to $7 \mu$, the majority being $2 \mu$ thick. A number of different stains were used. Satisfactory results were obtained with anilin, safranin, and gentian violet, with or without the orange $G$, with Heidenhain's iron-alum-haematoxylin, and with Bismarck brown and gentian violet.

Bischoff (8) in 1835 described and figured a number of species of Riccia, emphasizing the method of reproduction, and proposing the terms 'antheridia' and 'archegonia' for the male and female organs respectively. In 1836 a monograph on the Ricciaceae by Lindenberg (33) appeared. The earliest detailed account of the morphology of Riccia is by Hofmeister (25), who described the development of the thallus, the origin and position of the archegonia and antheridia, and the formation of the sporophyte. $\mathrm{He}$ remarks that the earlier investigators have described exclusively the organs of fructification, assuming that 'the low state of development of fruit must be accompanied by an equally low state of development of the vegetative organs'. ' Kny (30) investigated the structure of the thallus of various Ricciaceae and established its development by means of apical growth, showing the origin of the ventral scales, the sexual organs, and the nature of the air cavities. Fellner (20) is the first to record the development of a thallus of Riccia glauca from the spore. In a complete investigation by Leitgeb (32) of the following species of Riccia, $R$. glauca, $R$. bifurcata, $R$. crystallina, R. fluitans, R. Bischoffi, and Ricciocarpus natans, the development of the thallus and the origin and nature of the air-spaces are minutely described, together with some phases of the reproductive organs and sporophyte.

\section{Structure OF THE Thallus.}

The development of the thallus of $R$. Frostii, Aust., is in the main in accordance with that of other Ricciaceae as outlined by Campbell $(9$, p. 24). Growth takes place from one or more apical cells situated in a depression

1 Hofmeister: On the Higher Cryptogamia, p. 97. 
at the apex of the thallus. Like Riccia crystallina, Leitgeb (1. c., p. I3), the segments on the ventral side are limited and do not form ventral scales or lamellae, as they do in $R$. glauca (Campbell, l.c., p. 25). Fig. 6 represents a longitudinal vertical section cut through the growing point. It ends in a large wedge-shaped apical cell, from which cell-rows are cut off. On the dorsal side, segments are cut off which eventually become the upright filaments. A transverse section cut through the growing end of a thallus (Fig. 7) illustrates the dichotomous branching. The cell-rows cut off on either side arch over the growing point and are in an inclined or an almost horizontal position. In older parts of the thallus these cell-rows are erect. The growing points are distinguished by their dense contents and large nuclei.

Recent investigations of the air-chambers of the Marchantiales have brought into question the account of Leitgeb, who attributes the air-chamber and the sex-organ pit to the same origin in the Ricciaceae. His summary of the formation of the air-chambers and the stomata states that the origin of the air-spaces is caused by the growth of cells surrounding a depression which first appears on the surface. The continued upward growth of these cells forms the air-space, and the origin, therefore, is not due to a splitting from the outside inward, nor to a separation of cells. Goebel (23) states that the air cavities in the Riccieae do not arise schizogenetically like the intercellular spaces of higher plants, but in a manner as shown by Leitgeb, beginning in a depression at the junction of four cells, and originating as a natural consequence of the upward growth of the adjacent cells. Barnes and Land (4) studied the origin and nature of the air-chambers in the following forms: Fimbriaria, Marchantia, Lumularia, Conocephahs, Dumortiera, Plagiochasma, and Ricciocarpus natans and Riccia fluitans, and concluded that 'the air-chambers of the Marchantiales arise invariably by the splitting of internal cell-walls usually at the junction of the outermost and first internal layer of cells. Thence, in one type, splitting proceeds outwardly and inwardly more extensively than laterally, and lateral enlargement of the chamber follows by growth; while in the other type expansion of the chamber is due to extensive inward splitting accompanied by growth. The origin of the air-chamber is in all respects like that of the intercellular spaces in the vascular plants.' It is significant that Barnes and Land described only two forms of the Ricciaceae, and the two examined had the character of air-chamber of the other forms described by them.

Miss Hirsh (24), in a study of the air-chambers in the Ricciaceae based primarily upon Riccia Frostii, included the examination of fresh material of Ricciocarpus natans and herbarium material of Riccia nigrella, R. glauca, $R$. Miyakeana, R. crystallina, R. arvensis hirta, R. fluitans, and R. Donnellii. Her examination of Ricciocarpus natans confirms the statement of Barnes and Land that the air-spaces in this plant arise through internal cleavage 
and have no relation with the sex-organ pit, but in four of the other forms examined, $R$. nigrella, $R$. glauca, $R$. Miyakeana, and $R$. Frostii, a different type of air-chamber was found from that of Ricciocarpus natans and $R$. fluitans. Miss Hirsh, in describing the origin of the air-spaces in Riccia Frostii, Aust., says (1.c., p. 203), 'Immediately back of the apical cell the superficial cells arch outward in a papillate manner, as a result of the cessation of growth at the lines of their junction. As they elongate they are divided by transverse walls, so that filaments or rows of cells are formed, which are separate and distinct from one another. The intervening spaces in this species are formed, therefore, not by the cleavage or the separation of mature tissues, but in a manner exactly indicated by the diagrammatic scheme given by Barnes and Land in their Fig. I.' Miss Hirsh concludes that there are two methods of the origin of the air-spaces in the Ricciaceae: one, by internal cleavage resulting in irregular air-spaces separated by plates of cells one layer thick, as in Ricciocarpus natans; the other by the upward growth of filaments at right angles to the surface of the thallus, forming narrow chambers or canals, as in Riccia Frostii, Aust. It will be seen that Miss Hirsh supports the theory of Leitgeb, and her work is also in harmony with the description given by Campbell (1. c., p. 25). The writer's observations of Riccia Frostii are in agreement with those of Miss Hirsh.

Fig. 6 is a stage similar to Figs. 4, 5, and 6 of Miss Hirsh. The apical cell is seen at the apex, and back of this are depressions which become the air-spaces by the upward growth of the adjacent cells. The cell-row is seen to have become more than one cell thick in certain cells, initiating the widening of the air-spaces. The transverse section (Fig. 7) shows almost the same condition as the longitudinal in the papillate surface of the growing point, and at either side are the cell-rows with the canal-like air-spaces between them. The fully developed air-chamber is a canal of irregular polygonal shape, separated by plates of chlorophyll-bearing tissue, one cell in thickness, as seen in Fig. 8, a section cut parallel to the surface in a mature thallus. The number of cells bounding an air-space may therefore vary considerably in different parts of the thallus. This has been pointed out by Juel (28) in an article ${ }^{1}$ on Riccia Bischoffii. The small depressions or pits on the surface of the thallus are the openings of the airspaces which lead in an indefinite manner to the surface cells. The thallus of $R$. Frostii is similar to that of $R$. glauca described by Campbell (1. c., p. 28), and consists of the ventral part, a compact tissue with no air-spaces, from which the rhizoids spring. From this compact tissue the upright filaments arise, forming the elongated air-chambers. The terminal cells of the filaments are somewhat swollen and have scanty contents. Goebel (1. c., p. 72) refers to the lack of chlorophyll in the outermost layer of cells, and considers

1 From current literature in the Bot. Gaz., li, p. 479, I9I I. 
it a primitive form of epidermis. The upright filaments and the tissue beneath contain chlorophyll. The air-chambers in Riccia Frostii, Aust., are open their entire width, i.e. they are not overgrown by the surface development of the epidermis. An examination of Ricciocarpus natans ${ }^{1}$ and other -Marchantiales (Marchantia polymorpha, Fegatella conica, and Asterella) showed the origin of the air-spaces to be similar to that described by Barnes and Land. If the splitting occurs within the thallus in Riccia Frostii, Aust., it would seem reasonable to find stages that have not yet reached the surface, such as are found with no difficulty in Ricciocarpus natans and other forms. But in all the material examined the cell relations are unmistakably clear, and no stage was found with an internal space not yet broken out to the surface.

As before stated, the thallus of Riccia Frostii, Aust., is strictly dioecious. The sexual organs are scattered irregularly in acropetal succession in the thallus. Goebel (1.c., p. 80) speaks of the disposition of the sexual organs in Riccia as diffuse, and considers it a primitive type.

\section{Development of the Sexual Organs.}

Although several hundred slides were made of as many plants of Riccia Frostii, no sterile plants were found. No thallus was found, young or old, bearing both antheridia and archegonia. The sexual organs are produced continuously as long as the thallus lives. There is thus no definite fruiting period.

The development of the archegonia and antheridia conforms to the hepatic type, and has been fully described by other writers. The antheridium initial is distinguished by its dense contents from the adjacent cells before it projects above the surface of the thallus. The initial cell in Riccia Frostii divides transversely before it has projected much above the other cells. The antheridium scarcely projects above the surface of the thallus, for, as it elongates, the tissue immediately surrounding the antheridium develops, sometimes level with it (Fig. 10), sometimes a little lower than it (Fig. 9a), and eventually surpasses it (Figs. $9 b$ and II), leaving the antheridium an embedded or sunken structure. The antheridial wall is cut off early (Figs. I2 and I3). The end cells of the filaments adjacent to the antheridium are distinguished from the first by dense contents (Figs. $9 b$ and I1). These cells form the sanal, or opening, leading to the antheridium, through which the sperms are discharged (Fig. I3). Cell-division in the antheridium soon overtakes cell growth, and many cells eventually occupy the place of a few. As the antheridium matures, the cells of one group divide simultaneously. Usually several groups of cells are active, so that in one antheridium many stages of division may be found. The cells are

\footnotetext{
1 Slides belonging to Mr. Fermen L. Pickett.
} 
more or less cubical until the last division, which is a diagonal one, forming two triangular cells. Kny in Marchantia and Campbell in Fimbriaria report this final division without a cell-wall, as does Lewis (31) for Ricciocarpus natans. Durand (14) states that in slides stained with Delafield's haematoxylin the diagonal walls in Marchantia show distinctly in some cells, but seem to disappear early. The diagonal cell-walls were not found in Riccia Frostii, but at this stage in the antheridium the cell-walls appear to undergo a change, so that their detection may be a question of stage in development. The mature antheridium of Riccia Frostii has a short stalk, and is oval, with a flat base and rounded apex. The apex may be conical in young antheridia (Fig. I2). The size of the mature antheridium was found to vary; comparatively small antheridia were found with mature spermatozoids.

Before the sperms have been discharged from an antheridium they all eventually reach the same state of maturity and lie in a common cavity. All cell-walls in the antheridium disappear, and probably add to the semifluid contents of the antheridium. Several writers have observed the explosive discharge of sperms in various Liverworts. In Fegatella conica this was first observed by Thuret (40). King (29) and Cavers (10) have also studied the explosive discharge of sperms in Fegatella, and Peirce (38) in Asterella. While the discharge of the spermatozoids was not observed in Riccia Frostii, the following conditions point to their discharge as probably of an explosive nature. Antheridia when mature are filled with sperms, lying free in the cavity surrounded by the semi-fluid substance. The antheridium wall appears normal. In antheridia, where the sperms have been partly discharged, the cells in the wall of the antheridium are greatly distended inward. It would seem as if the pressure exerted by these cells would be sufficient to forcibly expel the spermatozoids. Antheridia are found emptied of their contents without any disturbance to surrounding cells, showing that the release of the spermatozoids is not due to a breaking down of tissue.

The complete account of the development of the archegonium in Riccia Bischoffi, by Janczewski (27), has been little modified by later investigators. The development of the archegonium is in general like that of the Liverwort archegonium described by Campbell, and by Garber (22) and Lewis for Ricciocarpus natans. In the paper by Durand (14) on Marchantia polymorphya, the steps in the development of the archegonium are so clearly presented and in such sequence that it is unnecessary to repeat them here. Various stages are seen in Figs. I4, I 5, and 16.

Actual fertilization was not observed. However, the sperm nucleus was observed in the egg-cell and in juxtaposition to the egg nucleus (Fig. I7). The fertilized egg probably undergoes a period of rest, as innumerable archegonia were found with the egg in the condition shown in 
Fig. I8. The nucleus is large, and the chromatin is collected in a cord or short segments. A fine network is seen in the nucleus besides the densely staining material. After fertilization, the venter of the archegonium, which is one cell thick, undergoes division, the cells at the base usually dividing first.

\section{The Sporophyte.}

The first division-wall in the fertilized egg is usually oblique, although inclined to be at right angles to the axis of the archegonium. Campbell, Garber, and Lewis report this division as usually horizontal, although sometimes oblique. The second division may be parallel to the first, resulting in a three-celled embryo, as in Fig. I9, or it may be at right angles, resulting in a globular embryo. Later divisions do not always follow the order described by Campbell, but the embryo gradually develops by irregular cell-division. The embryo, even when consisting of thirty or forty cells, may be oval (Fig. 2I), but is usually globular (Fig. 20). The amphithecium is developed according to Campbell ; sometimes this tabular row will be cut off early, or it may not be differentiated until quite late. In a growing embryo, several cells may be found in different stages of division, as seen in Figs. 24 and 25, which are from the same sporophyte. One is a late telophase with the chromatin in an apparent cord (Fig. 25). The other is a polar view showing sixteen chromosomes (Fig. 24).

By the time the spore mother-cells are formed, the amphithecium is partly disorganized. The inner layer of the sporangium wall is beginning to collapse, while the outer one appears comparatively firm. Many chloroplasts are seen in this layer (Fig. 23). The spore mother-cells round up, not entirely filling their cell cavities. The spore mother-cells do not completely fill the sporangium again until the spore tetrads are formed. The mucilaginous substance with which the spore mother-cells are surrounded stains homogenously with various stains, having great affinity for gentian violet and Bismarck brown. The nucleus of the spore mother-cell possesses a definite nucleolus. Lewis reports no definite nucleolus for Ricciocarpus natans, unless the mass of chromatin found in dividing nuclei be interpreted as such, but in Riccia Frostii these two stages seem to be differentiated. In material fixed with chrom-osmic-acetic acid mixture, oil drops are abundant in the spore mother-cell as black granules varying in size. Besides these, a dense network of lighter staining material fills the cell. The cell membrane is delicate. All the cells from the fertilized egg become spores except the amphithecium.

\section{Anomaly.}

The only abnormality observed is that in Fig. 22, in which the sporophyte has been affected by a bacterial organism. The neck of the archegonium is plugged by its mucilaginous contents. Below this the mass of 
Bacteria is seen. In the preparation this mass had stained brilliantly with the safranin, whereas the mucilaginous content of the neck had taken up the gentian violet. That the Bacteria were developing at the expense of the sporophyte is seen in the crushed cells beneath the developing colony. The cells of the sporophyte or of the surrounding gametophytic tissue are not invaded, but the Bacteria as a mass have pushed down or crowded the cells of the sporophyte. While it was difficult to distinguish individual Bacteria, the colony appeared to be composed of small, short rods. The entrance of the Bacteria may have been accomplished at the time of fertilization.

\section{SPOROGENESIS.}

Sporogenesis has been a favoured subject for investigation in many Liverworts. Farmer (16), studying the sporogenesis of Pallavicinia decipiens, describes a quadripolar spindle in the spore mother-cell, with each of the four rays projecting into a lobe of the cell. A note is included on Aneura multifida, in which the same condition is observed. In the latter plant a centrosphere, but no centrosome, was observed at the extremity of each ray. Farmer and Reeves (19), in Pellia epiphylla, Nees, found in dividing spores two centrospheres occurring on opposite poles of the nucleus, and apparently becoming a factor in the formation of the spindle. No centrosome could be demonstrated in the centrosphere. Farmer (17), in I 895, published a note on spore formation and karyokinesis in the Hepaticae, followed in the same year by a complete report of his results. In the later paper (18) various Hepaticae are studied. Farmer found two centrospheres in the archesporial divisions of Fossombronia at either end of the nucleus which was about to divide. A central body was sometimes distinguished. The centrospheres were not apparent in the newly-formed daughter nuclei until their walls had been formed. The spore mother-cells become somewhat four-lobed, but not as strikingly so as in some of the other Jungermanniaceae. Centrospheres appear simultaneously at four points on the periphery of the spore mother nucleus. The centrospheres become approximated in pairs and the first spindle is bipolar. In Pellia epiphylla, Farmer records that the centrosphere appears at four points on the periphery of the nucleus, and that each contains a small centrosome. Aneura multifida exhibits the same type of quadripolar spindle as that found in Fossombronia. The quadripolar spindle was not found in Fegatella conica. In germinating spores, centrospheres were distinguished. Davis (12), in studying Anthoceros, gives a complete history of the divisions in the spore mother-cell, emphasizing particularly the ontogeny of the chloroplast. He describes the appearance of threads around the nucleus, which later become the spindle fibres. No centrospheres were present. The poles of the spindle were flat, slightly convex, but never pointed. Van Hook (43) confirms the absence 
of centrospheres in Anthoceros spore mother-cells. In a later paper on Pellia, Davis (13) finds no centrospheres in the spore mother-cell, but in the germinating spore a centrosphere and an aster are observed. Chamberlain (11) finds centrospheres in the first mitosis of the germinating spore of Pellia. Moore (35) finds in Pallavicinia, that while the prophase resembles the four-poled spindle of Farmer, it cannot be interpreted as such, because it is followed by a well-organized bipolar spindle without centrospheres. Garber describes the sporophyte spindle of Ricciocarpus natans with prominent asters, but no centrosomes. Lewis for the same form finds neither centrosome nor centrosphere in the spore mother-cell divisions. Beer (5), in Riccia glanca, finds the resting nucleus of the spore mothercell with a large, deeply staining nucleolus and a number of more faintly staining linin fibres. He describes the nucleolus as a compound structure made up of a number of deeply staining chromatic masses or granules embedded in a more faintly staining matrix. In the prophase, a long spireme thread develops in contrast to the short thread described by Lewis for Ricciocarpus natans. The reduced number of chromosomes is seven or eight.

The spore mother-cells in Riccia Frostii afford only fair material for study. Although the cells and the nuclei are large, the spindle is small and the chromatin scanty. Almost all stages of division can be found in a sporophyte containing active spore mother-cells. The spore mother-cell in Fig. 26 presents the characteristic resting-stage of the nucleus, with a large nucleolus containing a few vacuoles. The rest of the nuclear content is distributed in a fine network around the nucleolus, not entirely filling the nuclear cavity. The exact nature of this is difficult to determine, as it stains very faintly. The cytoplasm, like that described by Lewis for Ricciocarpus natans, consists of a fine reticulum thickly embedded with granules. The black globules are especially prominent around the nucleus.

The spore mother-cells are spherical, lying free in the cavity of the sporophyte, surrounded by a semi-fluid substance. In all sporophytes found at this stage, the spore mother-cells were not crowded, there often being the width of a cell between one and its neighbours. The next stage observed (Fig. 27) shows the nucleus somewhat enlarged and elongated. Fibres are seen around the nucleus, and in a section showing the surface of this nucleus fibres extend across it. The chromatin is in the form of irregular lumps. Little is seen in the nucleus besides these lumps of densely staining chromatin. The formation of the spindle, from the stage seen in Fig. 27, was not observed. Some of the spindles found had decidedly pointed poles, but there was no indication of a centrosome or a centrosphere. The metaphase is seen in Fig. 28. The chromosomes appear as irregular dots, but are very short, curved rods. The cytoplasm in this and succeeding divisions remains the same. The spindle fibres are very distinct, some 
reaching from pole to pole, others ending at the equator, or diverging there into the cytoplasm. Fig. 29 shows the chromatin in irregular lumps at the poles. The spindle fibres are definite only to the equator, which appears granular. In Fig. 30 the daughter nuclei are formed with a definite nuclear membrane. They occupy a position very near the wall of the spore mothercell. Spindle fibres still connect the nuclei, some extend into the cytoplasm. There is a suggestion of cell-plate formation. The chromatin is in one or more irregular clumps, which are embedded in a faintly staining reticulum. The next figure (P1. XXXVIII, Fig. 3I) shows the nuclei in practically the same condition as in Fig. 30, and still very near the periphery of the spore mother-cell. An indefinite cell-plate is observed. A few spindle fibres extend from the daughter nuclei to the cell-plate. The cell-plate does not take in the complete diameter of the cell. In Fig. 32 the daughter nuclei have moved from the wall of the mother-cell, and now occupy an almost median position in either half of the cell. The cell-plate is distinctly granular, and extends only partly across the cell.

The second division in the spore mother-cell was found to be simultaneous in the two daughter nuclei. The spindles may lie in the same plane or at right angles to each other (Figs. 33 and 34). The spindle fibres are plainly seen, especially those apparently attached to the chromosomes. The spindle tapers to a point at the poles. The chromosome appears as a small, irregular-shaped lump, with a suggestion of a curve. In the polar views in Figs. 33 and 34, eight chromosomes are counted. No definite cell membrane was seen dividing the cell, although there is a suggestion of cleavage in the contents of the mother-cell between the dividing nuclei, indicating that a persistent cell-wall may or may not be formed in the first mitosis. Fig. 35 shows the formation of two of the daughter nuclei from the second division. The spindle fibres are distinct, but there is no indication of a cell-plate, although the cell contents appear divided. The daughter nuclei are small, with a very definite nuclear membrane. The chromatin is scanty, in several irregular lumps. There has been a gradual decrease in the size of the nucleus from spore mother-cell to spore. No centrospheres or centrosomes were seen in any stage in the division of the spore mother-cell.

\section{Development of the Spore.}

The development of the protective coverings of spores and pollengrains has received attention by numerous investigators since the publication of Strasburger's work (39) in I 882. A paper by Fitting (21) gave an impetus to further research, by his conclusion that the spore coats in Isoetes and Selaginella were formed independently of any direct connexion with the protoplasm of the spore. Miss Lyon (34), in studying the spore coats of 
Selaginella apus and S. mpestris, finds the protoplasm is in contact with the membrane-forming coats at every point. Beer (6), in the same year ('05), supports Fitting's theory, observing the same condition in Oenothera as does Tischler (41) for Mirabilis Falapa. Beer (7) believes that the spines and rodlets of pollen-grains of Ipomoea purpurea, Roth., develop independently of any direct protoplasmic influence. Beer (5) describes the development of the spores of Riccia glauca as follows: Upon the primary spore mother-cell walls secondary and later tertiary thickening layers are deposited. The secondary thickening layer is more or less mucilaginous. It sometimes separates completely from the primary wall. A plug of mucilage was observed just within the first spore wall at the equatorial rim. It has no direct relation to the developing layers. The second spore wall has three well-defined regions : an external, loosely laminated region, within this a dark layer, and an internal, densely laminated region. The endospore is formed later. Separating it and the second spore wall, there is often present a thin band of material. The protoplast of the spore is directly concerned in the development of the spore membrane.

Whatever the nature of the beginning of the walls in spore tetrads of Riccia Frostii may be, later development of the spore coat is accompanied by a close protoplasmic connexion. In general the development of the spore coats is similar to that described by Beer for Riccia glanca. The immature spore tetrad is shown in Fig. 36, with definite walls separating the spores. Inside this wall, which is a thin membrane and may be designated according to Miss Lyon as the 'mother-cell membrane', a second layer is formed. This is thicker, stains faintly with gentian violet, and appears of a gelatinous nature. It is connected by homogeneous strands, which appear to be of the same nature as the cytoplasm collected around the nucleus. The nuclei are small and contain usually one large and one or more smaller nucleoli embedded in a delicate reticulum. In Fig. 37 the cytoplasm appears more granular, and is seen extending in strands to all parts of the spore wall. Inside of the homogeneous gelatinous layer, and projecting into it in numerous small points, a layer develops which ultimately becomes the rough outer coat of the spore. The beginning of another layer is also distinguished inside of it. In the next figure (Fig. $3^{8}$ ) the projections have become more pronounced. The layer inside this appears striated. This layer corresponds to the second spore wall in R. glanca described by Beer. Eventually the endospore is formed. The developing exospore is yellow, then orange, and finally black. The sculpturing of this outer coat is shown in Fig. 39 in a surface view of a spore, and the projections correspond to cross-sections of an irregular system of ridges. No spores were observed except in the tetrad form, and the triangular appearance may not be characteristic of the individual spore. The plug of mucilage described by Beer for $R$. glauca was not observed in 
Riccia Frostii. The spore contains scanty cytoplasm, but is filled with food material, largely in the form of oil.

\section{The Spermogenous Cell.}

Numerous writers have observed that all of the cells in a given segment of an antheridium descended from one cell divide at the same time. In a large antheridium many stages may be found, and particularly successive stages. Inasmuch as the sperms are mature about the same time, the divisions in different parts of the antheridium follow one another closely. The nuclei in all of the spermogenous cells are comparatively large, almost filling the cell.

The spermatogenesis of Riccia Frostii, Aust., is difficult to follow, owing to the extreme smallness of the cells and their consequent blurred aspect when examined under high powers. A typical resting-stage similar to that in sporogenous cells was not observed in the cells in spermogenous tissue, nor was any stage found where a definite nucleolus could be distinguished. The most common condition is that shown in Fig. 40. The chromatin, which is abundant, is grouped in the centre of the nucleus in a number of irregular lumps. The rest of the nucleus, which is, on the whole, denser than the cytoplasm, is finely granular, or may have a definite reticulum. It appears homogeneous, and nothing could be seen distinctly in nuclei at this stage, except the mass of chromatin, which stains deeply. The cytoplasm is uniformly granular. Two cells in early prophase are shown in Fig. 4I. The chromatin is seen in a network of irregular lumps, evenly distributed in the nucleus; in one of them $(a)$ a central lump is present which resembles a nucleolus, but as the cells are small and some of the lumps quite large, it is possible that this body is a mass of chromatin which appears more globular than the others.

In Fig. 42 the chromatin has formed a definite thread or spireme. By focusing, this thread could be distinguished towards the periphery of the nuclear membrane, and is evidently the hollow spireme stage. The next observed stage is seen in Fig. 43. The spireme has evidently shortened and thickened, then segmented. The chromosomes are collected in the centre of the nucleus. The cytoplasm is uniformly granular. In Fig. 44 the nucleus is slightly elongated, and fibres extend beyond it, resembling polar caps. These fibres eventually replace the nuclear membrane (Figs. 45 and 46), and presumably are attached to the chromosomes. In Fig. 46 the separate chromosomes are distinguished a little more plainly than in Fig. 45 . The chromosomes, which appear as round, irregular lumps, are grouped at the equator (Figs. 47 and 48); the daughter chromosomes are always opposite. The spindle is pointed. Frequently a broad-poled spindle is seen, as in Figs. 52-54. The chromosomes appear as short, curved rods, as seen in the polar view (Figs. 49-5 ), and are eight in number. An interesting 
characteristic of the chromosome is that in larger cells the chromosomes are longer and comparatively slender, while in smaller cells they are short, thick rods, with a slight curve, as shown in Pl. XXXVII, Fig. 24, and Pl. XXXVIII, Figs. 49 and 5I. Fig. 48 shows two adjacent cells in metaphase. No stage was found showing the chromosomes on their way to the poles. Figs. 55 and $5^{6}$ show stages in late telophase.

The cells, previous to the diagonal division, were examined with particular reference to centrosome-like bodies. Frequently a spindle would be found with rather significant bodies at either pole, as represented in Fig. 48. Other granules, however, were found scattered through the cytoplasm, and, since optical phenomena would naturally make granules in a polar position appear more distinct, the presence of a definite body at the poles was considered doubtful in prediagonal mitoses.

\section{The Diagonal Division.}

The spermogenous cell previous to the last division is extremely small. With successive divisions in the spermogenous tissue the cells become smaller, and finally the oblique division is initiated. The nucleus (Fig. 57) is so small and stains so deeply, that little chromatin can be distinguished in it. No bodies at the poles could be demonstrated. But in Figs. $5^{8}$ and 59 the nucleus is found to be elongated in the direction of the diagonal axis of the cell, and at either pole is a definite body. Frequently more than one granule was found at or near the poles. These granules are apparently of kinoplasmic origin, and are no doubt a response to the same stimulus that is later realized in the blepharoplast, although not necessarily a definite phase in the development of the blepharoplast. The chromatin consists of a few scattered lumps, the forming chromosomes. The spindle is eventually formed, with a body at each pole (Fig. 60). The chromatin is collected at the equator, and in Figs. 61 and 62 the complete spindle is diagonally placed in the cell with the bodies terminating the axes. Polar views in Figs. 63 and 64 show the short curved chromosome.

Many spindles were seen in which it was impossible to distinguish a body at the poles, even with repeated staining. No stage was found showing the telophase or construction of the daughter nuclei. If a cell plate is suggested it does not persist, as the triangular cells resulting from the last division are found enclosed in the wall of the sperm mother-cell, with no wall separating them (Fig. 66). The polar granules disappear with the completion of the mitosis (Fig. 65). No evidence was found that they persist in the final oblique division, becoming the blepharoplasts.

There appears in these triangular cells a definite body, much more definite than the one discussed previously (Fig. 67). This body may occur in opposite angles of the two cells or in the same angle (Figs. 66 and 68). About this time the cell-walls break down and the triangular cells are free. 
They may lose their triangular shape, as seen in Figs. 69 and 70 , and eventually become somewhat rounded. Meantime, the body at the poles begins to elongate slightly, as shown in the same figures and in Fig. 66. This body is the origin of the blepharoplast.

\section{The Development of the Sperm.}

The development of the sperm in Riccia Frostii adds little that is new. The blepharoplast grows from an end which may be called the head or anterior end, and which is slightly larger than the posterior portion. It develops as an irregular cord, appearing somewhat granular (Figs. $7 \mathrm{I}$ and 72). Figs. $73-75$ show the blepharoplast in different positions. In Fig. 73 it is seen on the edge of the plasma membrane; in Fig. 74 a different angle is obtained, and the cord-like nature of the blepharoplast is observed. This figure is just reversed in Fig. 75, and the two ends of the blepharoplast are seen coming up from under the cell. The developing cell may be a somewhat elongated narrow cell, as seen in Figs. 7I-75, or it may become spherical, as in Figs. $76-78$. About this time a vacuole usually appears in the cytoplasm opposite the nucleus (Figs. 72, 76, and 77). This vacuole finally reaches the periphery of the cell (Figs. 79 and 80). The blepharoplast is now a cord extending about three-fourths of the way around the cell. The next step is the elongation of the nucleus, which becomes homogeneous, stains brilliantly with anilin safranin, and assumes the shape of a crescent (Fig. 80). The position of the nucleus also changes. In Fig. 80 the nucleus occupies the edge of the cell and is in contact with the blepharoplast. In Fig. 8I two cilia are seen developing from the blepharoplast, which is a narrow band connecting the head with the nucleus. The nucleus is a slender crescent and stains homogeneously. No distinction can be seen between the nucleus and blepharoplast, and it is impossible to tell how far the blepharoplast extends along the nucleus in this and succeeding figures. The crescent shape of the entire cell may be aided by the vacuole (Figs. 79-8I).

Figs. 82 and 83 , of a somewhat similar stage as Fig. $8 \mathrm{I}$, show two cilia grown out from the blepharoplast just back of the head. The head is a prominent part of the sperm, always staining more intensely than other parts. The cilia extend a little more than the circle of the sperm. In Fig. 84 the crescent-shaped nucleus is seen with the blepharoplast extending from the anterior end as a slender cord terminating in the darkly-staining head. Two cilia are attached at the base of the head and circle around the nucleus. In the curve of the nucleus is the somewhat granular cytoplasm. No extension of the blepharoplast is distinguished at the other extremity of the nucleus. The remaining cytoplasm or vesicle sometimes persists in a coil of the nucleus (Figs. 87 and 88), or it may disappear early (Fig. 86). As the sperm matures the blepharoplast becomes long, extending as a fine 
cord some little distance beyond the nucleus (Figs. 85-90). Both nucleus and blepharoplast elongate considerably, the nucleus thins and has about one and one-half coils, the cilia elongate, and the head persists as a distinct part of the sperm. Figs. 89 and 90 show the oldest sperms found in the antheridia. They may become more slender and more or less coiled just before they are discharged. The mature sperm then consists of the following parts : a homogeneous nuclear portion, the transformed nucleus of the sperm cell, and the cytoplasm, represented by a blepharoplast terminating in a head and bearing two cilia. A small amount of cytoplasm may persist as a vesicle.

In animal cells, the centrosome has been well established. The centrosome or the modified centrosome becomes an essential part of the mature animal spermatozoon (Wilson (47)). Chamberlain, in 'Mitosis in Pellia', concludes that centrosomes, centrospheres, and blepharoplasts are historically related, and with their radiations, spindle fibres, and cilia are only different manifestations of kinoplasmic activity - movement in all cases being the principal function. Webber $(44,45,46)$ does not consider the origin of the blepharoplast in Zamia a centrosome. Ikeno (26) considers the bodies found at the poles in Marchantia centrosomes, and that the centrosomes persist in the last division, becoming the blepharoplasts. Lewis does not believe the presence of the polar granules in spermogenous tissue in Ricciocarpus natans sufficient to warrant considering them true centrosomes. Woodburn (48) does not believe that the bodies occurring at the poles in the last division of Marchantia and Fegatella are true centrosomes, inasmuch as they have no genetic continuity, and in appearance and behaviour are not characteristic of centrosomes. Escoyez (15), in Marchantia, finds only in the last division the bodies which by their form and position resemble centrosomes. He adds that they are not true centrosomes, but organs sui generis, the blepharoplasts. Mottier (37), in discussing the homology of the blepharoplast and the centrosome, maintains that organs, to be homologous, must be organs in a morphological sense.

In a paper by Allen (1) on Polytrichum Funiperinum, Willd., the name 'androcyte' is suggested for the cell which will become the antherozoid. The cells of the penultimate generation are then the 'androcyte' mothercells, while a member of any other cell-generation within the antheridium is termed an 'androgone'. The last division is not diagonal. Kinoplasmic bodies appear in the cytoplasm of the 'androgones' as irregular plates or membranes. They are designated as 'polar plates', and are distinguished before there is any visible preparation for mitosis in the nucleus. The polar plate is divided transversely, and the daughter plates occupy positions on opposite sides of the nucleus. The spindle fibres grow out from them. These kinetosomes are considered by Allen to be unorganized masses of material used in the formation of the spindle fibres and cell plate. They remain during mitosis and are transferred from mother to daughter cell. 
The mitoses in the antheridial cells are further distinct from ordinary nuclear divisions by a swelling of the nucleus during a certain stage in the prophase and its final shrinkage. A definite body, from which fibres radiate, appears in the 'androcyte' mother-cell, and is referred to as a 'central body'. The 'central body' gives rise to two, which move apart and lie at opposite sides of the nucleus. They eventually occupy the poles of the spindle rudiment. As the nucleus swells and its membrane comes in contact with the central bodies, the further definition of these bodies becomes somewhat difficult. A definite body is found in each daughter cell, usually in the position of the former spindle-pole. This body is the blepharoplast. On p. I55 Allen says, "This position of the blepharoplasts, together with the other evidence already presented, seems to place beyond reasonable doubt the persistence during mitosis of the central bodies of the androcyte mother-cell and their identity with the blepharoplasts'; and, again, on p. I76: 'Whatever its homologies, the blepharoplast of Polytrichum is plainly a kinoplasmic body, manufactured out of materials already present in the "androcyte" mother-cell, perhaps from some of the very substance which in the "androgones" took the form of kinetosomes. But the blepharoplast is a definitely individualized cell organ, which the kinetosomes apparently are not; and although it is newly formed at a particular stage in ontogeny, there can be little doubt that it is an ancient structure phylogenetically.'

In this connexion it may be of interest to mention a paper by Balls (3) on the cytology of Egyptian Cotton. The separation of the chromosomes is affected by a conspicuous 'thread ring', to which the chromosomes are attached by means of spindle fibres. The insertions of the spindle fibres in the 'thread ring' appear as dots. The contraction of the dotted portion of the 'thread ring' gives rise to the bipolar spindle. In the telophase the chromosomes are retracted into the ring and the second division follows. In this way the continuity of the 'thread ring' is established. Balls 'hopes that the results obtained by the study of the fate of achromatic structures in higher plants will ultimately be translated into terms of the specialized centrosome of the lower plants and animals'.

The polar granules in Riccia Frostii have not been demonstrated as a constant factor in mitosis, and even where found they do not have genetic continuity. They have been observed only in the final spermogenous division. No definite origin could be determined for them. While the polar granule appears to play the part of a centrosome in cell division, in its behaviour and history it lacks many of the points which have been considered essential in a true centrosome. Until the qualities which are essential to a proper terminology of such bodies have been sufficiently demonstrated, it seems a little premature to designate the bodies in Riccia Frostii, Aust., as anything more definite than simply polar granules. The 
granule could not be shown to be the Anlage of the blepharoplast except for its position, for with the completion of the diagonal division it seems to disappear, and in an angle of the sperm cell there arises a more definite body which becomes the blepharoplast.

\section{SumMary.}

I. The thallus of Riccia Frostii, Aust., is dioecious. Growth by means of apical cells results in a circular thallus or rosette attached to the ground by simple rhizoids.

2. The air-chambers originate by the upward growth of adjacent filaments surrounding a depression at their junction. They are of various sizes. The mature air-chamber consists of a long, canal-like space separated by plates of chlorophyll-bearing tissue, one cell in thickness.

3. Sexual organs are produced early, and continue to be produced with the development of the thallus. There is no definite grouping of the reproductive organs. The development of the reproductive organs is similar to that of other species of Riccia.

4. The resting nucleus of the spore mother-cell contains a large nucleolus surrounded by a very fine network. The nucleus in the successive mitoses gradually decreases in size. No centrosomes or centrospheres are found in dividing spore mother-cells.

5. The spore contains a very small nucleus, surrounded by food material, largely in the form of oil. Two protective coverings are developed, due to the activity of the protoplast. The endospore is formed later. The sculpturing of the outer coat consists of an irregular system of ridges.

6. The last division in spermogenous tissue is placed diagonally in the cell, and is sometimes accompanied by granules at the poles. No cell-wall was found between the resulting triangular walls.

7. The blepharoplast is first distinguished in an angle of the cell as a sharply differentiated part of the cytoplasm. No evidence was found that showed the origin of the blepharoplast to be the polar granule in the preceding mitosis.

8. In the developing sperm the blepharoplast elongates as a cord. The nucleus assumes a crescent shape and becomes homogeneous. The cord-like blepharoplast becomes closely applied to the nucleus, extending from it as a narrow thread, terminating in a conspicuously thickened part or head from which two cilia are produced.

9. The mature sperm consists of a homogeneous nuclear portion, the transformed nucleus of the sperm cell, and the cytoplasm represented by a blepharoplast terminating in a head and bearing two cilia. A small amount of cytoplasm may persist as a vesicle. 
IO. The number of chromosomes is eight for the gametophyte, and sixteen for the sporophyte.

I I. An abnormal sporophyte was observed, caused by bacterial invasion.

The writer wishes to express her heartiest appreciation to Dr. David M. Mottier, at whose suggestion this study was carried on, for his assistance and kindly advice throughout its progress.

INDIANA UNIVERSITY, Bloomington, Indiana.

\section{LITERATURE.}

1. Allen, Charles E. : Cell Structure, Growth, and Division in the Antheridia of Polytrichum Juniperium. Archiv für Zellforschung, viii, Heft I, I912, pp. 12 I-88.

2. Austin, C. F. : Bull. Torr. Bot. Club, vi, No. 3 , I875, p. I 7 .

3. Balls, W. Lawrence: The Mechanism of Nuclear Division. Ann. Bot,, xxiv, igio, pp. $653-65$.

4. Barnes, C. R., and Land, W. J. G. : In Bryological Papers, The Origin of Air-chambers. Bot. Gaz., xliv, 1907, p. 2 I 3.

5. Beer, Rudolf: On the Development of Spores of Riccia glauca. Ann. Bot., xx, I906, pp. $275-9$ I.

6. Beih. z. Bot. Centralbl., Abt. I9, i, Heft 2, 1905, pp. 286-31 3.

7. : Studies in Spore-Development. Ann. Bot., xxv, I9I I, pp. I99-2I 4.

8. Bischoff, G. W.: Bemerkungen über die Lebermoose, vorzüglich aus den Gruppen der Marchantieen und Riccieen. Acad. Caes. Leop., Nova Acta, xvii, 1835, pp. 909-I088.

9. Campbell, D. H.: Mosses and Ferns. Macmillan \& Co., I905.

10. Cavers, F.: Explosive Discharge of Antherozoids in Fegatella conica. Ann. Bot., xvii, I903, pp. $270-4$.

11. Chamberlain, C. J. : Mitosis in Pellia. Bot. Gaz., xxxv, 1903, pp. 28-5I, Pl. XII-XIV.

12. Davis, B. M.: The Spore Mother-Cell of Anthoceros. Bot. Gaz., xxviii, I899, p. 89.

13. - Nuclear Studies on Pellia. Ann. Bot., xv, I90I, pp. 147-180.

14. Durand, E. J.: The Development of the Sexual Organs and Sporogonium of Marchantia polymorpha. Bull. Torr. Bot. Club, xxxv, I908, pp. 32I-36, Pl. XXI-XXV.

15. Escoyez, Eud.: Blépharoplaste et centrosome dans le Marchantia polymorpha. La Cellule, xxiv, $2^{\mathrm{e}}$ fas., $1907, \mathrm{pp} .247-56$.

16. Farmer, J. B.: Studies in Hepaticae: On Pallavicinia decipiens, Mitten. Ann. Bot., viii, I 894, pp. $35^{-} 5^{2}$.

17. $:$ Spore-Formation and Karyokinensis in Hepaticae. Ann. Bot., ix, I895, pp. $363-4$.

18. : On Spore-Formation and Nuclear Division in Hepaticae. Ann. Bot., ix, 1895, pp. $469-524$.

19. Ann. Bot., viii, I894, pp. 2 I9-24.

20. Fellner : Über die Keimung der Sporen von Riccia glauca. Jahresber. d. Acad. d. Naturw. Vereines in Graz, 1875 .

21. Fitting, Hans : Bau und Entwickelungsgeschichte der Makrosporen von Isoetes und Selaginella, \&c. Bot. Zeit., lviii, 1900, pp. 107-64. 
22. Garber, J. F. : The Life-history of Ricciocarpus natans. Bot. Gaz., xxxvii, I904, pp. I6 I-77.

23. Goebel, K. : Organography of Plants, Part II. English Edition, 1905.

24. Hirsh, Pauline E.: The Development of Air Chambers in the Ricciaceae. Bull. Torr. Bot. Club, xxxvii, I9I0, p. 73 .

25. Hofmeister, W.: Vergleichende Untersuchungen der höheren Kryptogamen. English translation. The Higher Cryptogamia, Ray Society, I862.

26. Ikeno, S.: Die Spermatogenese von Marchantia polymorpha. Beihefte zum Botanischen Centralblatt, xv, I 903, pp. $65_{-88}$.

27. Janczewski, E. von: Vergleichende Untersuchungen über die Entwickelungsgeschichte des Archegoniums. Bot. Zeit., I873, xxx.

28. Juel, O.: Ueber den anatomischen Bau von Riccia Bischoffii, Hub. Svensk. Bot. Tidsk., iv, I9Iо, pp. г6о-6.

29. King, C. A. : Explosive Discharge of Antherozoids in Conocephalum. Torrya, iii, I903, pp. 60-I.

30. KNy : Über Bau und Entwickelung der Riccieen. Jahrb. f. wiss. Bot., v, I866-67, pp. 364-86.

31. Lewis, C. E.: The Embryology and Development of Riccia hutescens and Riccia crystallina. Bot. Gaz., xli, 1906, pp. 109-38.

32. Leitgeb, H.: Untersuchungen über die Lebermoose. 4. Die Riccieen, I879, pp. I-Ior.

33. Lindenberg, J. B. W. : Monographie der Riccieen. Acad. Caes。 Leop., Nova Acta, xviii, I 836 , pp. $3^{61-504}$.

34. Lyon, Florence: The Spore Coats of Selaginella. Bot. Gaz., xl, 1905, pp. 285-95.

35. Moore, A. C. : The Mitosis in the Spore Mother-Cell of Pallavicinia. Bot. Gaz., xxxvi, I903, pp. $3^{8} 4-8$.

36. MotTier, D. M.: Beiträge zur Kenntniss der Kerntheilung in den Pollen-Mutterzellen einiger Dikotylen und Monokotylen. Jahrb. wiss. Bot., xxx, I 897, pp. I69-204.

37. - The Development of the Spermatozoid in Chara. Ann. Bot,, xviii, I904, pp. $245-54$.

38. Peirce, G. J. : Forcible Discharge of Antherozoids in Asterella Californica. Bull. Torr. Bot. Club, xxix, 1902, pp. 374-82.

39. Strasburger, E. : Ueber den Bau und das Wachsthum der Zellhäute. Jena, r 882.

40. Thuret, G. : Discharge of Antherozoids in Fegatella. Mém. de la Soc. des Sciences nat. de Cherbourg, iv, I856, p. 216.

41. Tischler, G.: Zellstudien an sterilen Bastardpflanzen. Archiv f. Zellforschung, i, Heft I, I908, pp. 33-I $5^{\text {I. }}$.

42. Underwood, L. M. : Systematic Botany of North America: Hepaticeae, ix, Part I, I895.

43. Van Hook, J. M. : Notes on the Division of the Cell and Nucleus in Liverworts. Bot. Gaz., $\mathrm{xxx}, \mathrm{I} 900, \mathrm{p} .394$.

44. Webber, H. J. : Peculiar Structures occurring in the Pollen-tube of Zamia. Bot. Gaz., xxiii, I897, pp. $453-59$.

45. : The Development of the Antherozoids of Zamia. Bot. Gaz., xxiv, I897, pp. I6-22.

46. : Notes on the Fecundation of Zamia and the Pollen-tube-Apparatus of Ginkgo. Bot. Gaz., xxiv, I 897 , pp. 225-36.

47. Wilson, E. B. : The Cell in Development and Inheritance. Macmillan \& Co., I 906.

48. Woodburn, Wm. L. : Spermatogenesis in certain Hepaticae. Ann. Bot., xxv, I9ir, pp. 299-3 3. 


\title{
EXPLANATION OF FIGURES IN PLATES XXXVII AND XXXVIII.
}

\author{
Illustrating Miss Black's paper on Riccia Frostii.
}

Fig. I-5 were photographed by Miss C. F. Kephart. Magnification 4 diameters.

All drawings were made with the aid of a camera-lucida. A Zeiss microscope was used with apochromatic objectives I $6,8,4$ and $2 \mathrm{~mm}$. n. A I $\cdot 30$, and compensating oculars 4,8 , I2, and $\mathrm{I} 8$. The drawings were made on a drawing-board, except those of spermatogenesis, which were drawn at table level.

\section{PLATE XXXVII.}

Fig. I. Complete thallus, illustrating the typical compact rosette.

Fig. 2. A thallus, showing irregular growth. plant.

Fig. 3. A portion of a young thallus, illustrating the prominence or individual lobes of the divisions.

Fig. 4. Part of a complete rosette, showing how the thallus separates along the original

Fig. 5. A young thallus, showing irregular growth.

Fig. 6. Longitudinal section through the growing end of the thallus, showing the wedge-shaped apical cell. The origin of the air-chambers is shown in the depressions between the cells. $\times 500$.

Fig. 7. A transverse section cut through the growing end of the thallus, showing the two growing points. The young cell rows are in an inclined, almost horizontal, position. $\times 250$.

Fig. 8. Cross-section of the mature air-chambers, showing irregular polygonal shape and varying size. $\times 250$.

Fig. $9 a$. The stalk mother-cell and the mother-cell of the antheridium proper. Antheridium initial projects slightly. $\times 500$.

Fig. 9 b. Young antheridium, becoming embedded in sex-organ pit. $\times 500$.

Fig. Io. Young antheridium scarcely projecting above the surface. $\times 500$.

Fig. I I. Antheridium, showing characteristic tip cells of surrounding filaments. $\times 500$.

Fig. I 2. Cutting off of the antheridial wall. $\times 500$.

Fig. I3. End cells of filaments adjacent to antheridium have formed a canal leading to the antheridium. $\times 250$.

Fig. I4. First division of primary cell of archegonium. $\times 500$.

Fig. 15. Two-celled archegonium. $\times 500$.

Fig. 16. Three-celled archegonium. $\times 500$.

Fig. I7. Fertilization. $\times 500$.

Fig. I8. Resting condition of the fertilized egg. $\times 500$.

Fig. 19. Three-celled embryo. $\times 5 \mathrm{co}$.

Fig. 20. Small globular embryo. $\times 250$.

Fig. 21. Oval embryo. $\times 250$.

Fig. 22. Abnormal sporophyte affected by bacterial invasion. $\times 500$. $\times 250$

Fig. 23. Sporophyte with spore mother-cells. The amphithecium is partly disorganized.

Fig. 24. Polar views of the metaphase in a dividing sporophyte cell, showing sixteen long curved chromosomes. $\times 2250$.

Fig. 25. Telophase of a dividing sporophyte cell. $\times 2250$.

Fig. 26. Resting-stage of the spore mother-cell, showing the prominent nucleolus and the delicate network around it. $\times 1,500$.

Fig. 27. Nucleus of spore mother-cell somewhat elongated, with fibres around the nuclear membrane. The chromatin is in irregular lumps. $\times 1,500$. 
Fig. 28. Metaphase in the spore mother-cell. The chromosomes are seen as densely staining granules. The poles of the spindles are well defined. $\times$ I,500.

Fig. 29. Telophase. Spindle fibres are distinct only to the equator, which is somewhat granular. $\times$ I, 500 .

Fig. 30. Formation of the daughter nuclei. Indication of cell plate shown. Spindle fibres very distinctly seen. $\times \mathrm{I}, 500$.

\section{PLATE XXXVIII.}

Fig. 3I. The cell plate is more distinct than in Fig. $30 . \times$ I, 500 .

Fig. 32. The daughter nuclei have moved from the periphery of the spore mother-cell wall, and occupy a median position between it and the cell plate. The cell plate appears as a granular line, and does not extend entirely across the cell. $\times \mathrm{I}, 500$.

Fig. 33. Metaphase of the daughter nuclei. Spindles are in the same plane. Polar view of chromosomes shows the reduced number to be eight. $\times 1,500$.

Fig. 34. Similar stage to Fig. 33, showing one spindle. The spindle is small and tapers to a point at the poles. $\times I, 500$.

Fig. 35. Formation of the danghter nuclei. $\times 1,500$.

Fig. 36. Spore tetrad. Nuclei are very small, with the chromatin in one or more lumps. $\times$ I, 000 .

Fig. 37. A heavy line is formed inside of the gelatinous layer. This becomes eventually the outer spore wall. $\times \mathrm{I}, 000$.

Fig. 38. Inside of the rough spore wall another layer is added. This layer appears striated. Contents of cell becoming more granular. $\times \mathrm{I}, 000$.

Fig. 39. Surface view of almost mature spore, showing sculpturing of outer spore coat. $\times I, 000$.

\section{Spermatogenesis.}

The following drawings were made at table level with a magnification of about 3,000 times :

Fig. 40. Spermogenous cell with the chromatin clnmped together irregularly in the nucleus. The nucleus on the whole is denser than the cytoplasm.

Fig. 4I. Two cells in early prophase. The chromatin is seen in a network of irregular lumps.

Fig. 42. Hollow spireme. The nucleus almost fills the cell.

Fig. 43. The spireme is segmented and the chromosomes occupy the central part of the nucleus.

Fig. 44. The nucleus is slightly elongated.

Fig. 45. The spindles are replacing the nuclear membrane.

Fig. 46. Similar to Fig. 45. Chromosomes are more distinct.

Fig. 47. Metaphase. Well-defined spindle with pointed poles. The chromosomes are opposite each other at the equator.

Fig. 48. Stages similar to Fig. 47 .

Figs. 49-5I. Polar views of metaphases, showing eight chromosomes, the reduced number. The chromosomes are short, curved rods.

Figs. 52-54. Broad-poled spindles.

Fig. 55. Telophase. No polar granules observed.

Fig. 56. Formation of the daughter nuclei. Cell plate is being laid down.

Fig. 57. The spermogenous cell previous to the last division.

Fig. $5^{8}$. The nucleus has elongated, and in the corners of the cells at opposite sides of the nucleus are two granules.

Fig. 59. Similar to Fig. $5^{8}$.

Fig. 6o. Formation of the spindle fibres. The chromatin is collected in a lump.

Fig. 6r. The oblique spindle, with the chromosomes in the equatorial plate and the spindle fibres terminating in the polar granules.

Fig. 62. Similar to Fig. 61.

Figs. 63 and 64 . Polar views of the oblique division, showing eight short, curved chromosomes.

Fig. 65. Two diagonal cells with no indication of the polar granules.

Fig. 66. The diagonal division completed. Sperm cells lying free within the wall of the sperm mother-cell.

Fig. 67. Diagonal cell showing definite body in one of the angles of the cell.

Fig. 68. Two sperm cells resulting from the oblique division, with the blepharoplasts in the same angle of the cell. 

cord.

Figs. 69, 70. The sperm cell rounds up somewhat. The blepharoplast is elongating as a narrow

Fig. $7 \mathrm{r}$. Sperm cells showing the elongation of the blepharoplast.

Fig. 72. Vacuole appearing in cytoplasm.

Fig. 73. Blepharoplast seen as a cord on the periphery of the plasma membrane.

Fig. 74. View of blepharoplast.

Fig. 75. View as in Fig. 74 reversed, showing the two ends of the blepharoplast.

Fig. 76. Vacuole appearing in the cytoplasm. Blepharoplast somewhat extended.

Fig. 77. Definite vacuole in the cytoplasm. Blepharoplast consists of a cord on the periphery of the cell, extending a little more than half-way round.

Fig. 78. Showing round form of developing sperm. Blepharoplast as in Fig. 77 .

Fig. 79. Sperm assuming crescent shape.

Fig. 80. Nucleus becoming homogeneous, and sperm is more crescent-shaped than in Fig. 79.

Fig. 81. Nucleus homogeneous and crescent-shaped. Blepharoplast extending from it and terminating in a head from which two cilia arise. Cytoplasm caught in the curve of the nucleus.

Figs. 82,83 . Two sperms of the same stage, one with cytoplasm in the curve of the nucleus. The head is very definite and the cilia have elongated.

Fig. 84 . Similar to Figs. 82 and 83 . Head of sperm very definite.

Fig. 85. Sperm has elongated somewhat. Very little cytoplasm in the coil of the nucleus.

Fig. 86. Little later development. Blepharoplast, nucleus, and cilia elongated.

Fig. 87. About the same as Fig. 86, sperm with cytoplasmic vesicle.

Figs. 88, 89. Definite head, which stains deeper than any other part of sperm. In Fig. 89 nucleus and blepharoplast somewhat separated.

Fig. 90. Mature sperm, showing head, long slender blepharoplast to which nucleus is applied, and the two slender cilia. 
Annats of Botany,
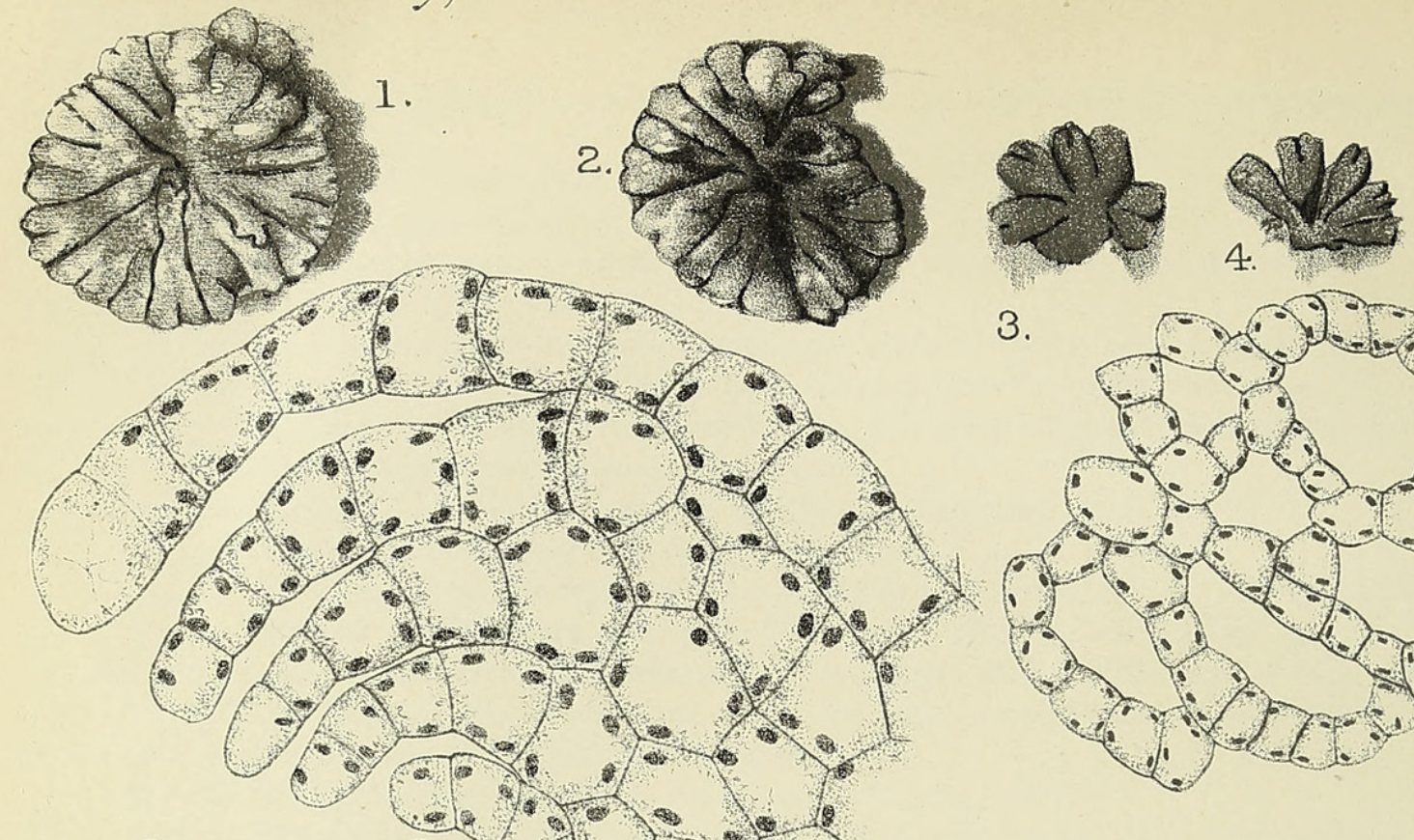

3. 5 . 5

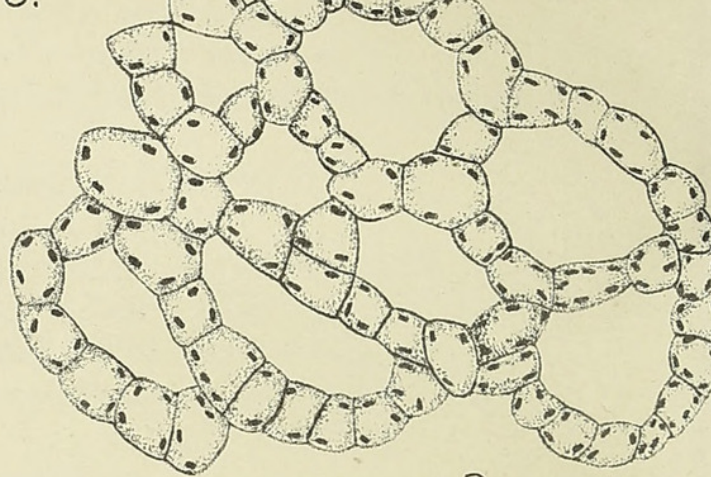

6.

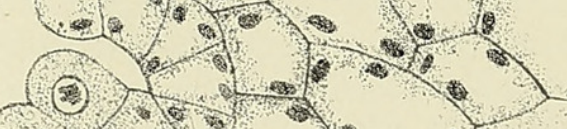

(8) $(0)=0$ oे

(39) (3) (3) (3) (3)

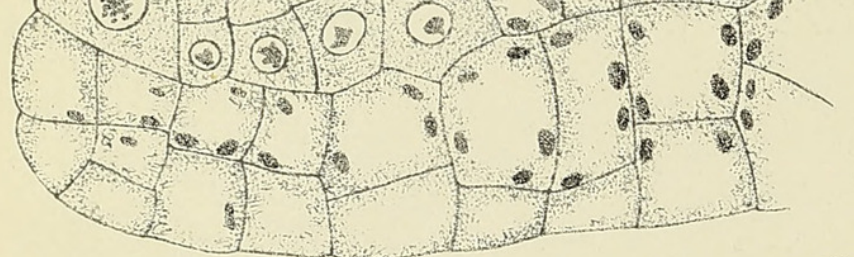
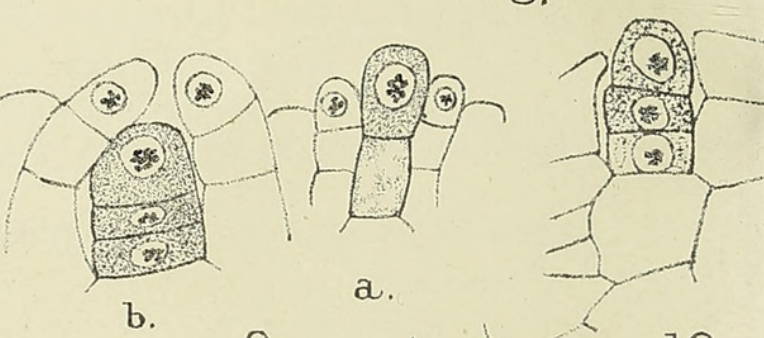

$+10$
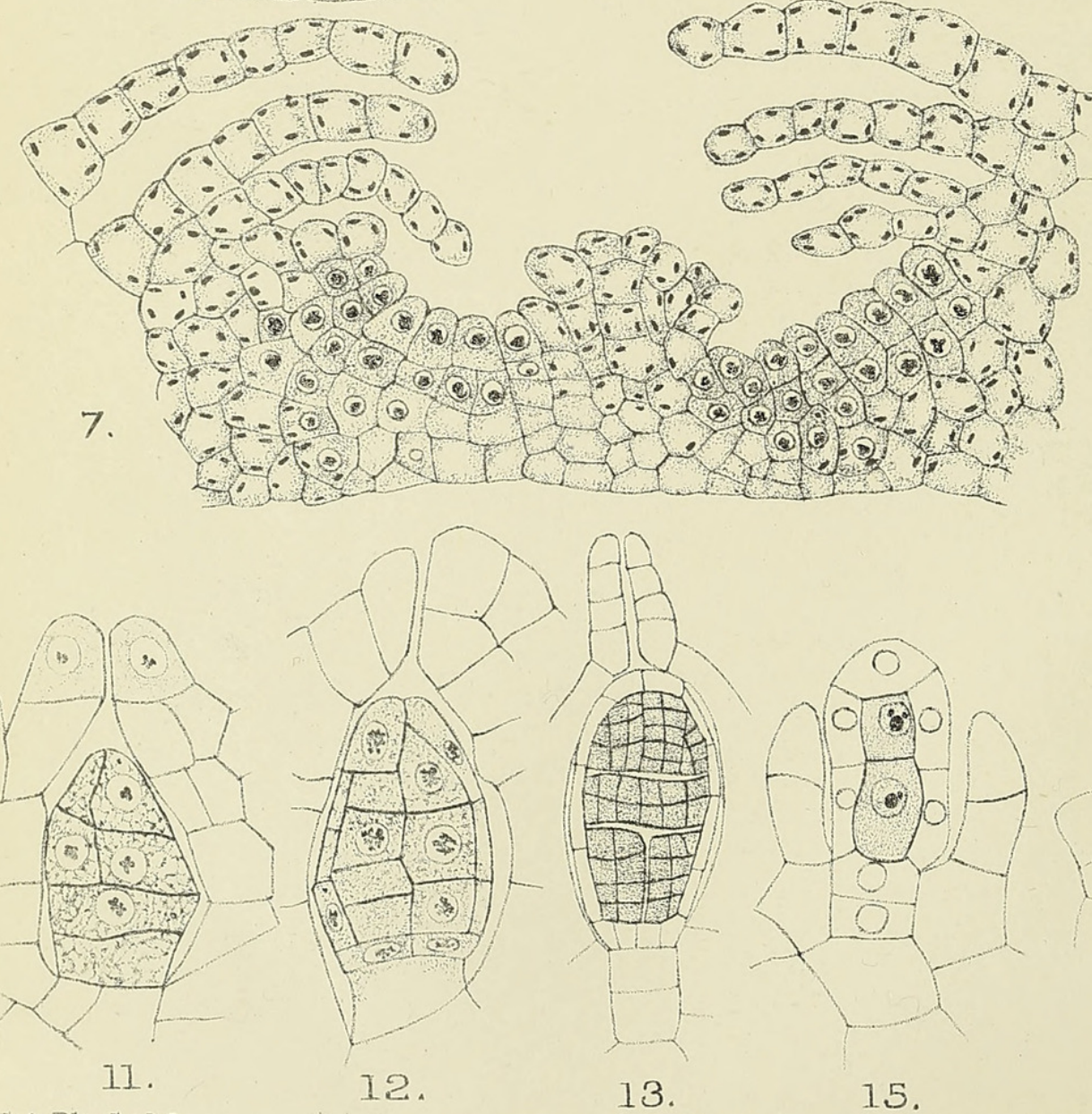

14.

A.Black, del.

BLACK - RICCIA FROSTII. 
Vol. XXVII, PZ, XXXVII.

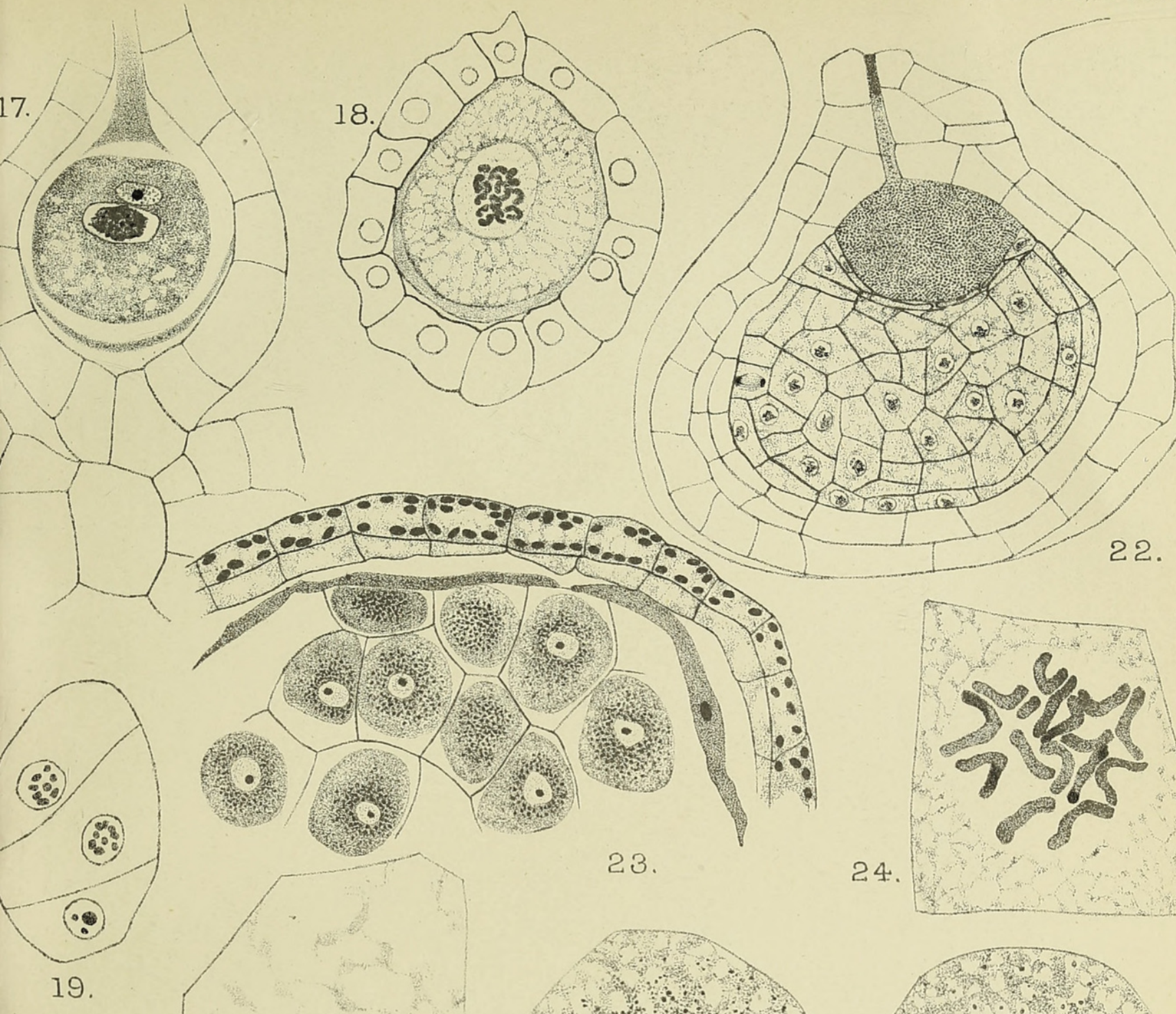

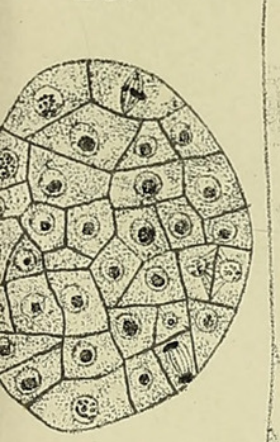

21

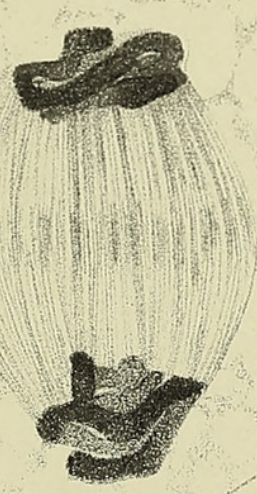

25

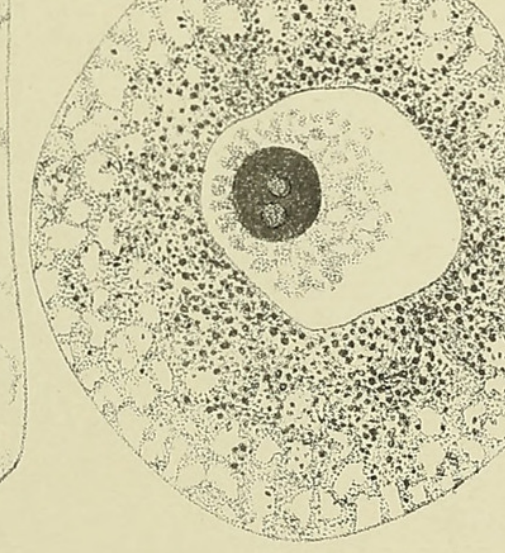

26

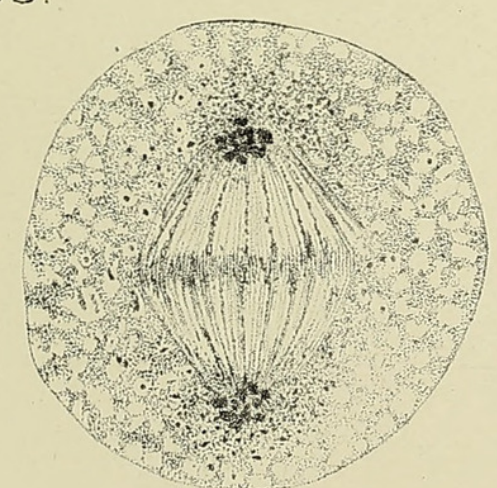

29.

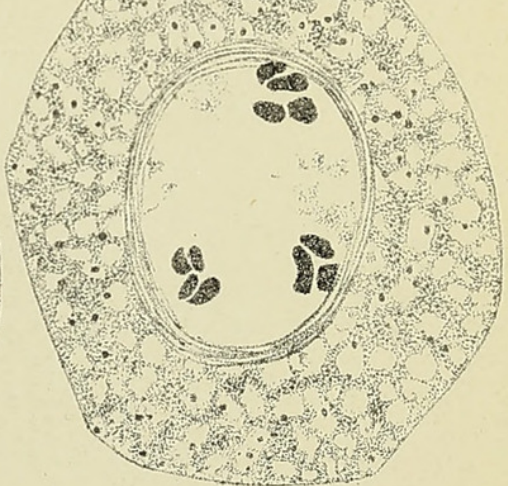

27.

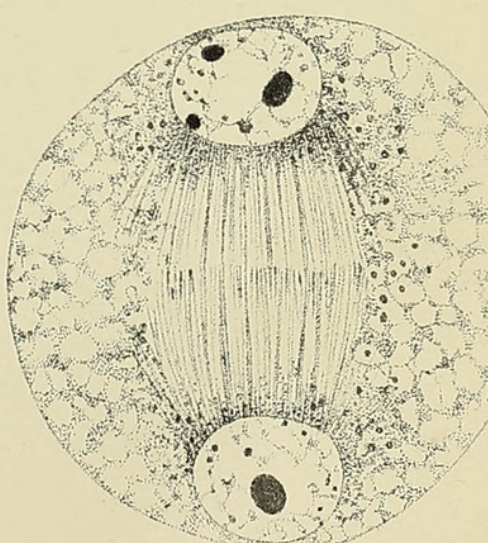

30 
Annals of Botany,
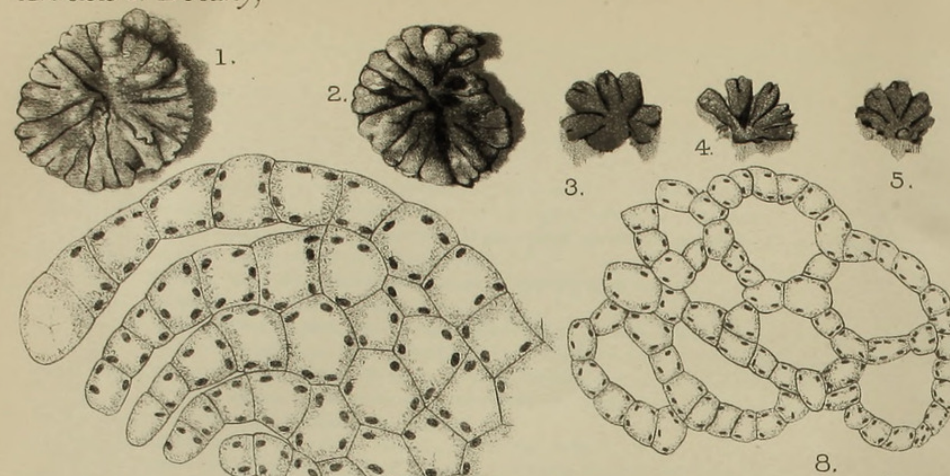

and

8.

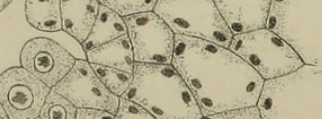

(3) (3) (3) 0.

(10) (3) (3): $\because$

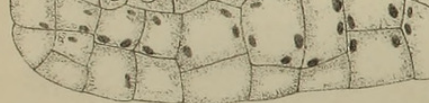

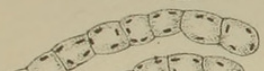

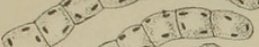

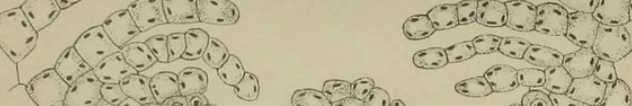

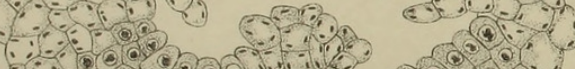

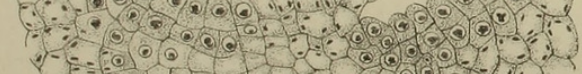

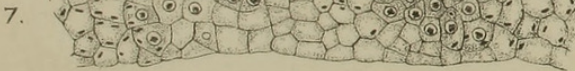

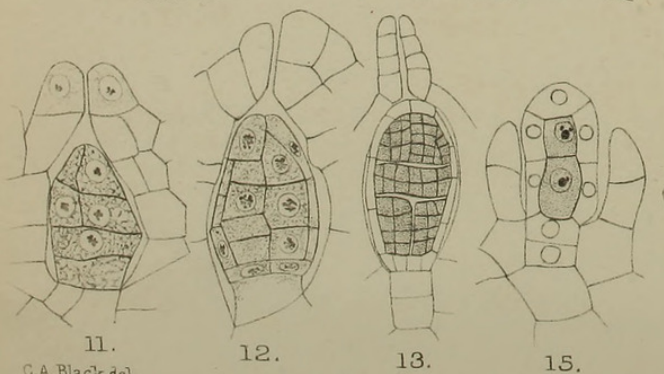

G.A. Black, del.

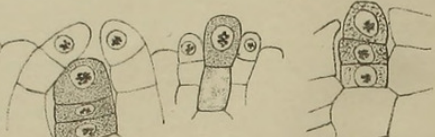

b.

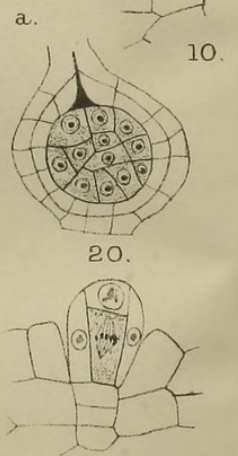

14.

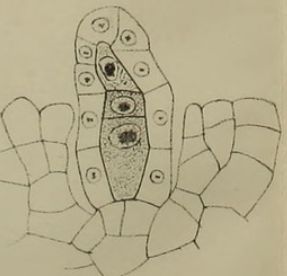

16.

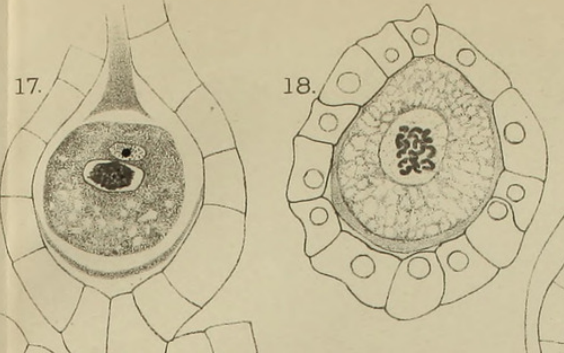

Vol. XXVII, Pl. XXXVII.

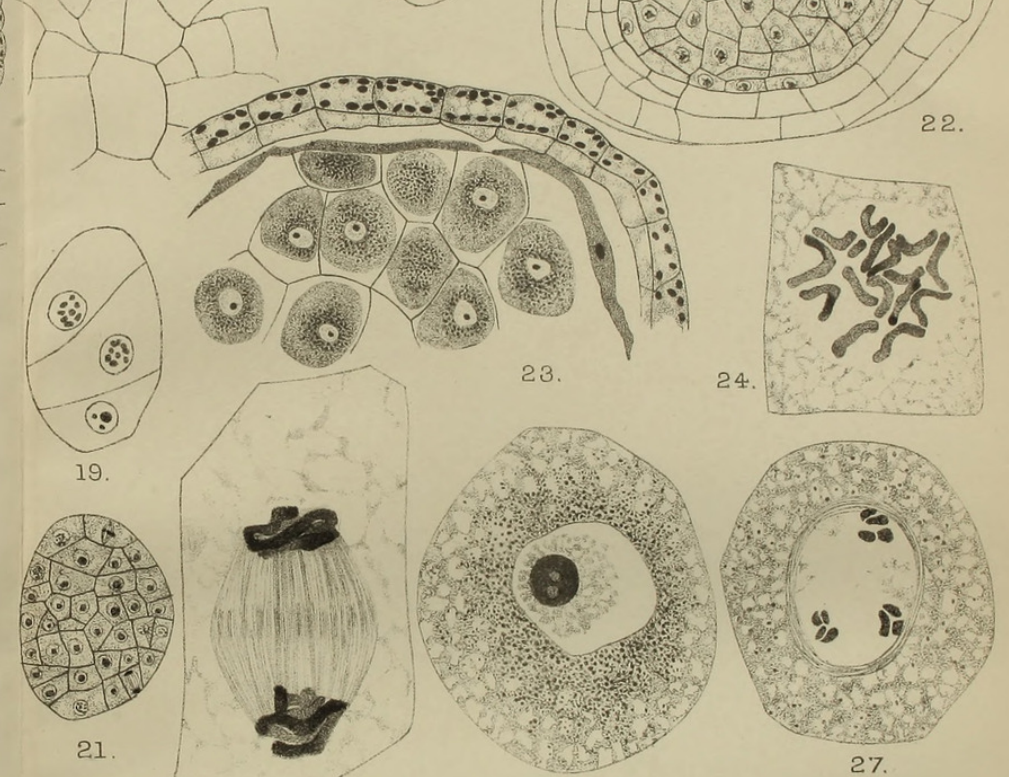

21
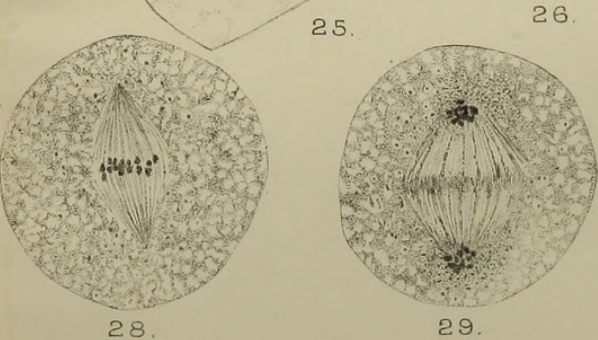

29

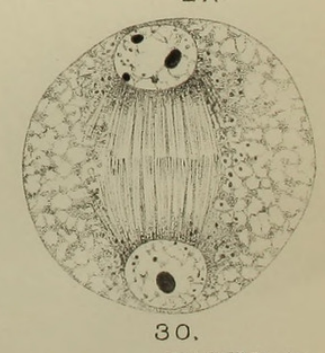

Hutb, LittY Londo 
Annals of Botany,

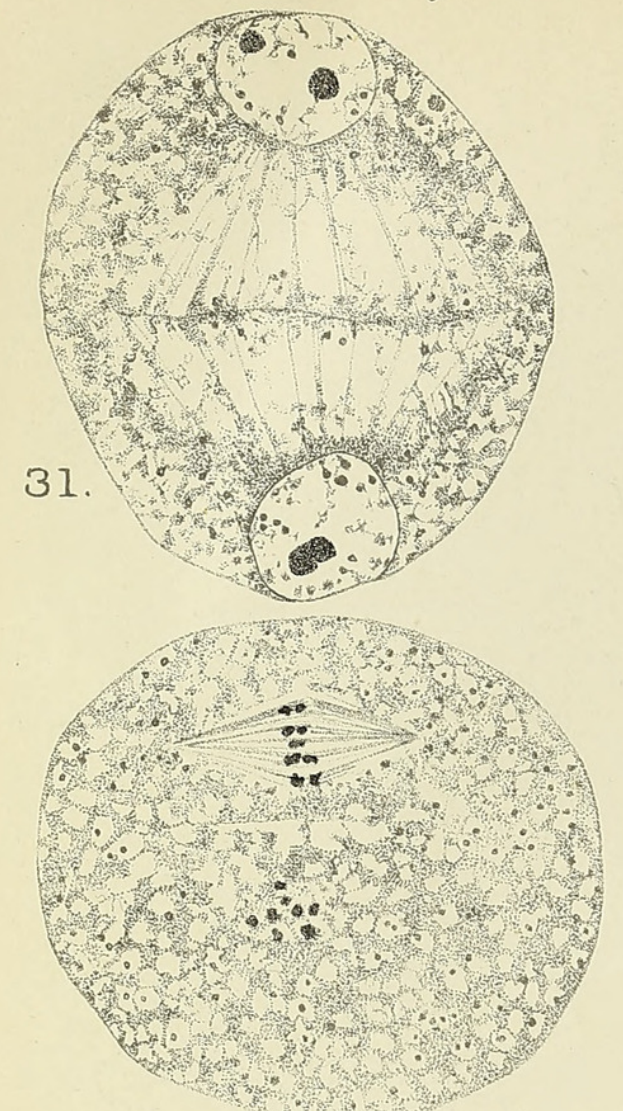

$$
34 .
$$


35 .

36.
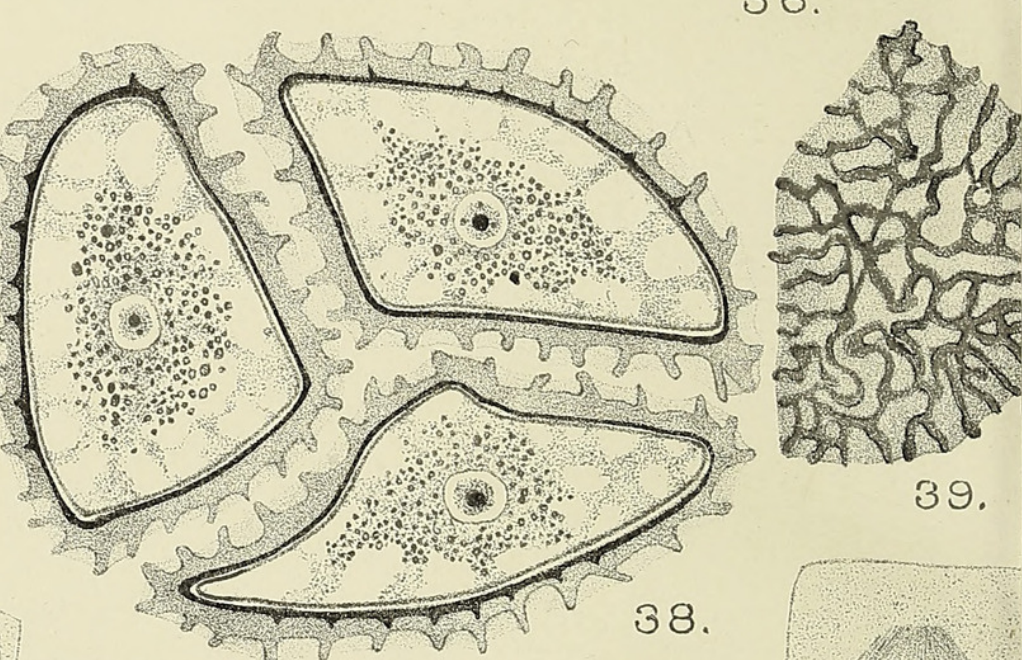

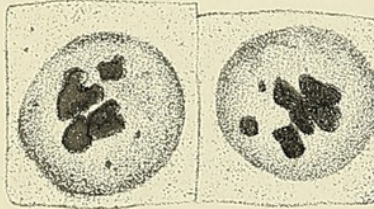

40

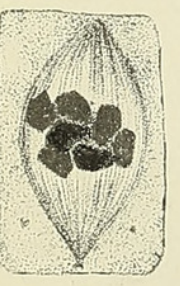

45.

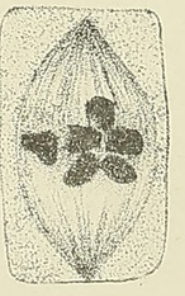

46.
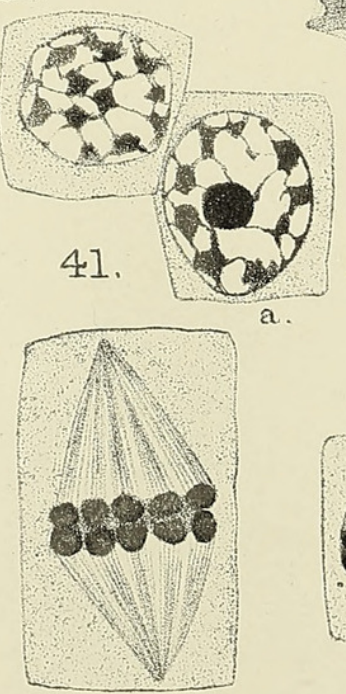

47.

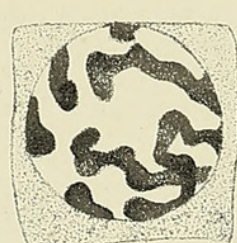

42

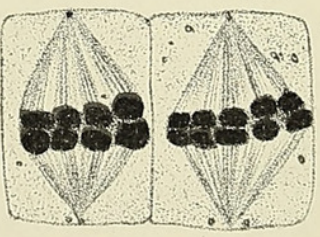

48.

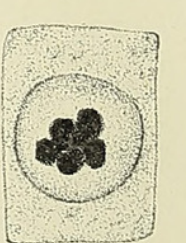

43.

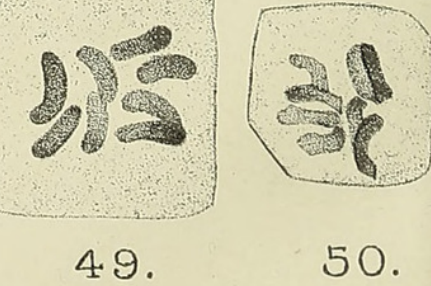

C.A. Black dèl.

BLACK - RICCIA FROSTII 
Annals of Botany,

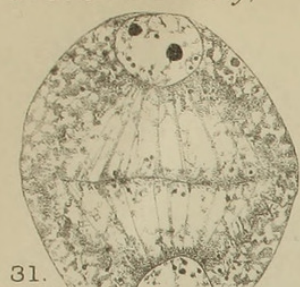

31.

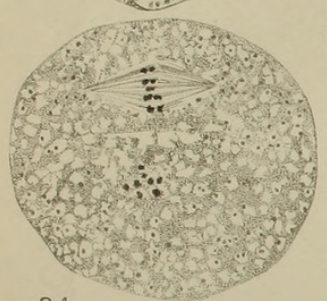

34.

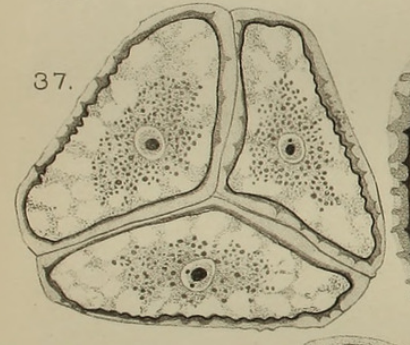

(8) $*$ 40.
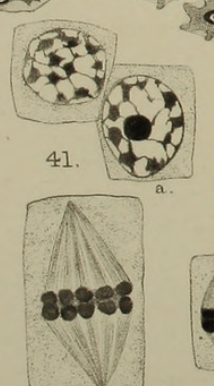

45.

C.A.Black del.

2. से

46.
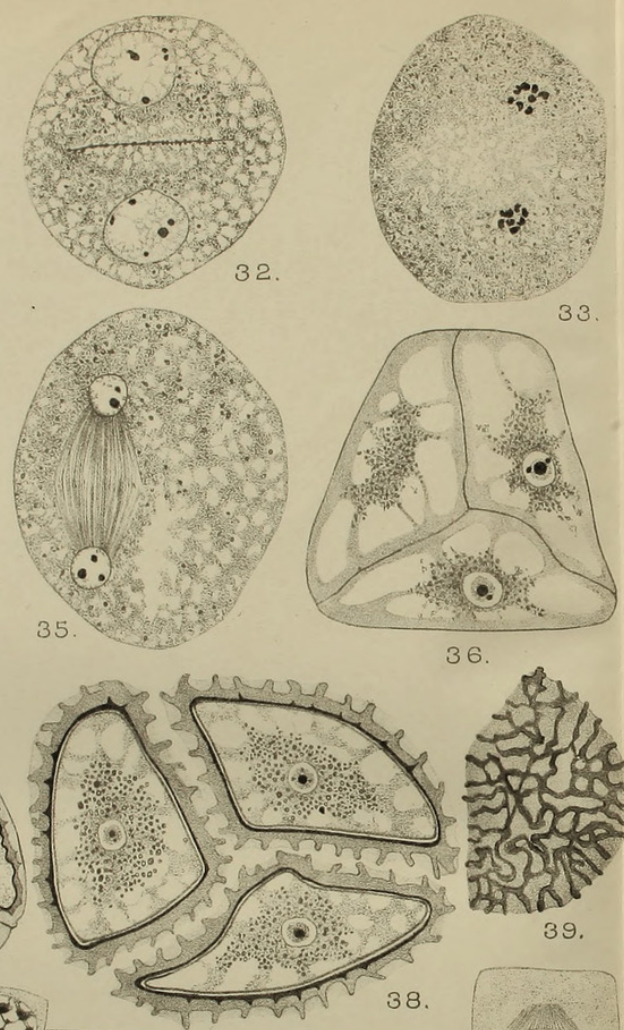

\section{.6}
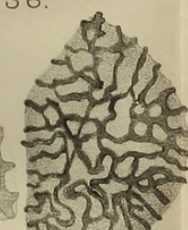

20
51
6

$56 .-57$

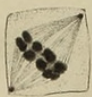

61.

0

66

(e)
71.
(6)

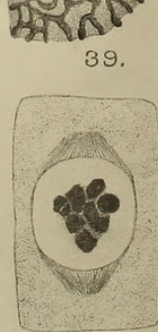

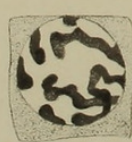

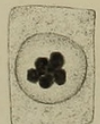

43 .

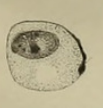

76.

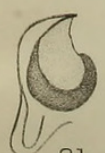

81

2) कह और

49.

50.

0
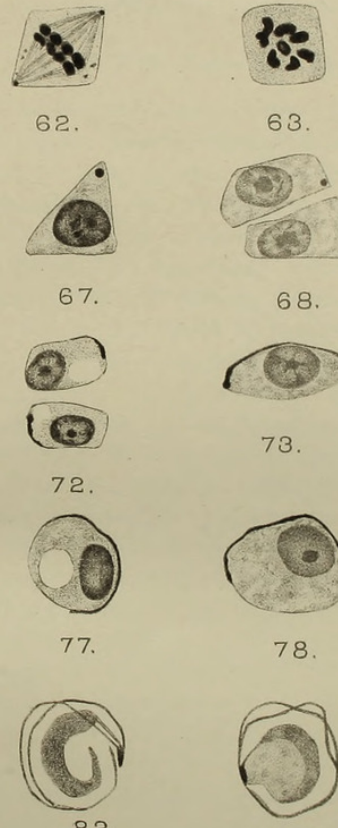

62.

․ㅜㅇ

67.

8

$(6)$

72.

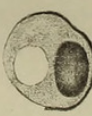

0

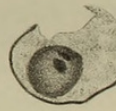

:80

64

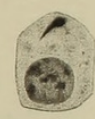

6

68.

(2)

(2)

(B)

75.

83.

$\therefore$
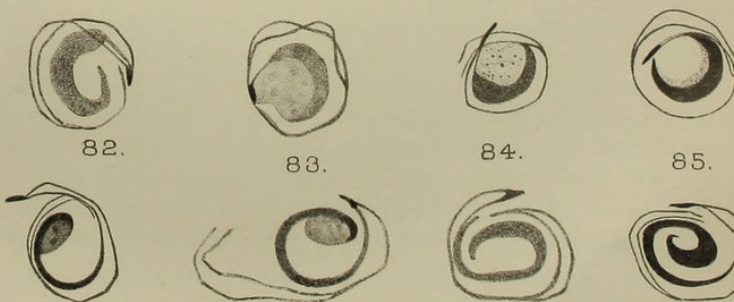

(a)

88.

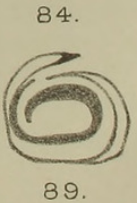

85.

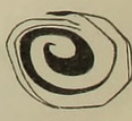

90. 


\section{$2 \mathrm{BHL}$ Biodiversity Heritage Library}

Black, Caroline A. 1913. "The morphology of Riccia frostii, Aust." Annals of botany 27, 511-532. https://doi.org/10.1093/oxfordjournals.aob.a089472.

View This Item Online: https://www.biodiversitylibrary.org/item/237410

DOI: https://doi.org/10.1093/oxfordjournals.aob.a089472

Permalink: https://www.biodiversitylibrary.org/partpdf/319985

\section{Holding Institution}

Smithsonian Libraries

\section{Sponsored by}

Biodiversity Heritage Library

\section{Copyright \& Reuse}

Copyright Status: Not in copyright. The BHL knows of no copyright restrictions on this item.

This document was created from content at the Biodiversity Heritage Library, the world's largest open access digital library for biodiversity literature and archives. Visit BHL at https://www.biodiversitylibrary.org. 